\title{
Infrared Absorption and Emission Spectra of Carbon Monoxide in the Region from 4 to 6 Microns
}

\author{
Earle K. Plyler, Lamdin R. Blaine, and Eugene D. Tidwell
}

\begin{abstract}
The infrared absorption and emission spectra of carbon monoxide and carbon dioxide have been measured with high resolution in the region from 4 to 6 microns. The measurements of the $\mathrm{C}^{12} \mathrm{O}^{16}$ fundamental band were carried out to a high precision, and a set of molecular constants were calculated from the experimental data. In emission the $1-0$ and $2-1$ bands of $\mathrm{CO}$ were measured in the $P$ branch. Twenty lines of $\mathrm{C}^{13} \mathrm{O}^{16}$ were measured in absorption, and the molecular constants were calculated for this molecule. The fundamental band of $\mathrm{CO}_{2}$ was found to have its center at $2,349.16, B_{0}=0.39026 \pm 0.00005$, and $D_{0}=12.6 \pm 0.8 \times 10^{-8} \mathrm{~cm}^{-1}$. figures.

The complete emission spectra of $\mathrm{CO}$ and $\mathrm{CO}_{2}$ from 4 to 6 microns are shown in two
\end{abstract}

\section{Introduction}

The infrared absorption spectra of $\mathrm{CO}$ and $\mathrm{CO}_{2}$ have been measured by many observers in the region from 4 to $6 \mu$ [1]. ${ }^{2}$ The previous results showed the rotational properties of the bands, but the individual lines were not measured with sufficient precision for an accurate determination of the band's centers or the other molecular constants. The emission spectra of $\mathrm{CO}$ and $\mathrm{CO}_{2}$ have also been the subject of a brief report [2], but a precise measurement of the rotational lines was not made.

The present work was carried out for the purpose of making a more precise determination of the wavelengths of the fundamental bands of these two molecules in emission and absorption, so that both sets of data could be used in the determination of the molecular constants. The improvement in the precision of the measurements was made possible primarily by the use of a Fabry-Perot interferometer for a comparison spectrum and by further calibration with standard atomic lines from enclosed ares of xenon and krypton.

\section{Experimental Method}

An infrared grating spectrometer was used for the resolving instrument. Measurements were made with two gratings, one with 4,572 lines/in. and another one with 7,500 lines/in. Each grating had a surface with rulings about $5 \frac{1}{2} \mathrm{in}$. high and extended over 8 in. From 4 to $5.5 \mu$ better resolution was obtained with the 7,500 lines/in. grating. In the absorption measurements lines separated by $0.2 \mathrm{~cm}^{-1}$ were resolved and in emission lines separated by $0.3 \mathrm{~cm}^{-1}$ were resolved. By the use of a synchronous motor and a precision gear drive, the grating is slowly turned so that the spectral region from 4 to $5.8 \mu$ is scanned.

The details of the optical system and the arrangement of the interferometer, absorption cell and sources have been previously described [3]. A cooled

\footnotetext{
1 This research was supported by the Office of Naval Research.
}

2 Figures in brackets indicate the literature references at the end of this paper.
PbTe photoconducting cell was used as the detector for the infrared radiation. A 1P28 photomultiplier was used as a detector of the visible fringe system produced by the Fabry-Perot interferometer. One amplifier is used with the photomultiplier, and a second one is used to amplify the signal changes of the $\mathrm{PbTe}$ cell. The output of the amplifiers are recorded on a two-pen recorder, and the recorded fringe system superimposed on the absorption spectrum throughout the band. In order to relate the fringe system is to definite wave numbers for measuring the absorption spectrum, higher orders of standard lines of xenon and krypton, which are detected by the $\mathrm{Pb}$ Te cell, are superimposed on the chart.

By having the standard lines detected along the same optical path as the absorption spectrum, any errors that would be produced by a different optical path of the interferometer are avoided. By this method the fringe system is used for the determination of equal intervals of wavenumbers, and the absolute position of the band is determined by the standard lines.

In the measurements of this region the spacer of the interferometer was about $2 \mathrm{~mm}$ in thickness, and the separation of maxima of the visible fringe system, observed in the tenth order, was equal to $0.28 \mathrm{~cm}^{-1}$ in the $5 \mu$ region.

\section{Experimental Results}

The observed spectra are shown in figures 1 through 4 . In figure 1 is shown the $4.26 \mu$ absorption band of $\mathrm{CO}_{2}$ present in $6 \mathrm{~m}$ of laboratory air. On account of the low transmittance in the center of the band for about the first 15 lines in both the $P$ and $R$ branches, accurate measurement could not be made in that region. The $4.26 \mu$ band of $\mathrm{CO}_{2}$ is also overlapped by the two isotopic molecules, $\mathrm{C}^{13} \mathrm{O}_{2}{ }^{16}$ and $\mathrm{C}^{12} \mathrm{O}^{16} \mathrm{O}^{18}$. In addition a higher state, or hot band, of normal $\mathrm{CO}_{2}$ should have appreciable intensity for this quantity of gas. With a vacuum instrument and measurements at reduced pressures of the $\mathrm{CO}_{2}$ gas. it would be possible to resolve many rotational lines of the three molecules. The extra lines seen in the region from 2,290 to $2,330 \mathrm{~cm}^{-1}$ are 
in most part due to the $\mathrm{C}^{13} \mathrm{O}_{2}{ }^{16}$ molecule. The $P$ branch of the band of $\mathrm{C}^{13} \mathrm{O}_{2}{ }^{16}$ is not so strongly overlapped, and a number of the lines have been measured. In the use of the lines of $\mathrm{CO}_{2}$ from 2,290 to $2,330 \mathrm{~cm}^{-1}$ for calibration, it is necessary to take into consideration the spectral slitwidth of the instrument employed, as the lines will change their position with varying resolution. In table 1 is given a list of the measured lines and the calculated and observed wavenumbers; the molecular constants calculated from these measurements are given in the last section of this report.

In figure 2 is shown the emission spectrum of $\mathrm{CO}_{2}$. The spectrum in emission was observed from the flame of a glass blower's torch. A rich mixture of methane gas and oxygen was burned, as this type of flame gave good intensity for the emission bands of $\mathrm{CO}$ and $\mathrm{CO}_{2}$. The two bandheads, 001-000 and $01^{1} 1-01^{1} 0$, of the $\mathrm{CO}_{2}$ emission spectrum are very prominent at the high frequency part of the spectrum. In between these two band heads are a number of the emission lines of the $R$ branch of the $\mathrm{CO}_{2}$ band. 'In the region beyond the two band heads there is overlapping of the emission spectrum of the flame and the absorption spectrum of atmospheric $\mathrm{CO}_{2}$. The atmospheric absorption is so great that very few lines or other band heads are observed in the region

TABLE 1. Observed and calculated rotational lines of $\mathrm{C}^{12} \mathrm{O}_{2}^{16}$ and $\mathrm{C}^{13} \mathrm{O}_{2}{ }^{16}$

\begin{tabular}{|c|c|c|c|c|c|c|c|}
\hline & \multicolumn{2}{|c|}{$\mathrm{C}^{12} \mathrm{O}_{2}{ }^{16}$} & \multirow{2}{*}{$\begin{array}{c}\text { Devia- } \\
\text { tion } \\
\text { Obs-calc }\end{array}$} & & \multicolumn{2}{|c|}{$\mathrm{C}^{12} \mathrm{O}_{2}{ }^{16}$} & \multirow{2}{*}{$\begin{array}{c}\text { Devia- } \\
\text { tion } \\
\text { Obs-calc }\end{array}$} \\
\hline & Observed & $\begin{array}{l}\text { Calcu- } \\
\text { lated }\end{array}$ & & & Observed & $\begin{array}{l}\text { Calcu- } \\
\text { lated }\end{array}$ & \\
\hline & $\mathrm{cm}^{-1}$ & $\mathrm{~cm}^{-1}$ & $c m^{-1}$ & & $\mathrm{~cm}^{-1}$ & $\mathrm{~cm}^{-1}$ & $\mathrm{~cm}^{-1}$ \\
\hline P 58 & 2293. 762 & 2293. 764 & $0.002-$ & P 48 & 2304. 785 & 2304. 774 & 0.011 \\
\hline 56 & 2295.984 & 2296.014 & $.030-$ & 46 & 2306. 911 & 2306. 904 & .007 \\
\hline 50 & 2302.645 & 2302. 620 & .025 & 2 & 2347.569 & 2347.593 & $.024-$ \\
\hline R 30 & 2370.310 & 2370.274 & .036 & R 60 & 2384.958 & 2384.962 & $.004-$ \\
\hline 32 & 2371. 431 & 2371.430 & .001 & 62 & 2385. 741 & 2385.738 & .003 \\
\hline 34 & 2372. 602 & 2372.561 & .041 & 64 & 2386. 498 & 2386. 489 & .009 \\
\hline 36 & 2373. 662 & 2373. 666 & $.004-$ & 66 & 2387. 211 & 2387. 214 & $.003-$ \\
\hline 38 & 2374. 741 & 2374. 747 & $.006-$ & 68 & 2387. 923 & 2387. 914 & .009 \\
\hline 40 & 2375. 778 & 2375.802 & $.024-$ & 70 & 2388. 591 & 2388.588 & .003 \\
\hline 42 & 2376. 823 & 2376. 832 & $.009-$ & 72 & 2389. 273 & 2389. 236 & .037 \\
\hline 44 & 2377.828 & 2377.837 & $.009-$ & 74 & 2389.862 & 2389. 859 & .003 \\
\hline 46 & 2378.810 & 2378.816 & $.006-$ & 76 & 2390.444 & 2390.456 & $.012-$ \\
\hline 48 & 2379. 751 & 2379.770 & $.019-$ & 78 & 2391.049 & 2391.069 & $.020-$ \\
\hline 50 & 2380.691 & 2380.699 & $.008-$ & 80 & 2391.556 & 2391.574 & $.018-$ \\
\hline 52 & 2381. 600 & 2381.602 & $.002-$ & 82 & 2392.105 & 2392. 094 & 011 \\
\hline 54 & 2382. 462 & 2382.480 & $.018-$ & 86 & 2393. 043 & 2393. 057 & $.014-$ \\
\hline 56 & 2383. 335 & 2383. 333 & .002 & 88 & 2393. 503 & 2393. 500 & .003 \\
\hline \multirow[t]{3}{*}{58} & 2384. 163 & 2384. 160 & .003 & 90 & 2393.905 & 2393. 917 & $.012-$ \\
\hline & \multicolumn{2}{|c|}{$\mathrm{C}^{13} \mathrm{O}_{2}{ }^{16}$} & \multirow{2}{*}{$\begin{array}{c}\text { Devia- } \\
\text { tion } \\
\text { Obs-calc }\end{array}$} & & \multicolumn{2}{|c|}{$\mathrm{C}^{13} \mathrm{O}_{2}{ }^{16}$} & \multirow{2}{*}{$\begin{array}{c}\text { Devia- } \\
\text { tion } \\
\text { Obs-calc }\end{array}$} \\
\hline & Observed & $\begin{array}{l}\text { Calcu- } \\
\text { lated }\end{array}$ & & & Observed & $\begin{array}{l}\text { Calcu- } \\
\text { lated }\end{array}$ & \\
\hline & $\mathrm{cm}^{-1}$ & $\mathrm{~cm}^{-1}$ & $\mathrm{~cm}^{-1}$ & & $\mathrm{~cm}^{-1}$ & $\mathrm{~cm}^{-1}$ & $\mathrm{~cm}^{-1}$ \\
\hline P 44 & 2245.610 & 2245.613 & $0.003-$ & P 24 & 2264.960 & 2264. 969 & $0.009-$ \\
\hline 42 & 2247.660 & 2247.658 & .002 & 22 & 2266.759 & 2266.771 & $.012-$ \\
\hline 40 & 2249. 682 & 2249.678 & .004 & 20 & 2268.547 & 2268.549 & $.002-$ \\
\hline 38 & 2251.671 & 2251.675 & $.004-$ & 18 & 2270.313 & 2270.303 & .010 \\
\hline 32 & 2257.521 & 2257.518 & .003 & 14 & 2273.744 & 2273.738 & .006 \\
\hline 30 & 2259.420 & 2259.417 & .003 & 10 & 2277.076 & 2277.076 & .000 \\
\hline 28 & 2261. 296 & 2261. 292 & .004 & 8 & 2278. 708 & 2278.708 & .000 \\
\hline 26 & 2263. 144 & 2263.143 & .001 & 6 & 2280.314 & 2280.316 & $.002-$ \\
\hline
\end{tabular}

from 2,310 to $2,375 \mathrm{~cm}^{-1}$. The spectral lines, which are prominent in the region from 2,250 to $2,310 \mathrm{~cm}^{-1}$, are produced by the absorption of $\mathrm{C}^{12} \mathrm{O}_{2}{ }^{16}$ and $\mathrm{C}^{13} \mathrm{O}_{2}{ }^{16}$. Twenty lines of the $P$ branch of $\mathrm{C}^{13} \mathrm{O}_{2}{ }^{16}$ were measured in absorption and are given in table 2. The band center, $\nu_{0}$, was found to be $2,285.056 \pm 0.014 \mathrm{~cm}^{-1}$.

From 2,220 to $2,250 \mathrm{~cm}^{-1}$ several emission lines of the $R$ branch of the $1-0$ band of CO have been identified. They are overlapped by other lines and could not be measured to as high a precision as in absorption.

Figure 3 is a continuation to $1,940 \mathrm{~cm}^{-1}$ of the emission spectrum shown in figure 2. The rotational lines in this region primarily belong to the $1-0,2-1$, and 3-2 transitions of CO. Seventeen of the rotational lines of the 1-0 band of $\mathrm{CO}$ have been measured to a high precision and were included with the absorption data in calculating the molecular constants of CO. Twenty lines of the 2-1 band were also measured, and the observed and calculated values are listed in table $2, \nu_{0}=2,116.80 \mathrm{~cm}^{-1}$ for $2-1$ transition. In the region from 1,860 to $2,050 \mathrm{~cm}^{-1}$, some of the emission lines of the $\mathrm{H}_{2} \mathrm{O}$ molecule appear in the spectrum.

TABLE 2. Observed and calculated rotational lines of $\mathrm{C}^{12} \mathrm{O}^{16}(2-1), \mathrm{C}^{13} \mathrm{O}^{16}, \mathrm{C}^{12} \mathrm{O}^{18}$

\begin{tabular}{|c|c|c|c|c|c|c|c|}
\hline & \multicolumn{2}{|c|}{$\mathrm{C}^{12} \mathrm{O}^{16}(2-1)$} & \multirow{2}{*}{$\begin{array}{c}\text { Devi- } \\
\text { ation } \\
\text { obs-calc }\end{array}$} & & \multicolumn{2}{|c|}{$\mathrm{C}^{12} \mathrm{O}^{16}(2-1)$} & \multirow{2}{*}{$\begin{array}{c}\text { Devi- } \\
\text { ation } \\
\text { obs-calc }\end{array}$} \\
\hline & Observed & $\begin{array}{l}\text { Calcu- } \\
\text { lated }\end{array}$ & & & Observed & $\begin{array}{l}\text { Calcu- } \\
\text { lated }\end{array}$ & \\
\hline & $\mathrm{cm}^{-1}$ & $\mathrm{~cm}^{-1}$ & $\mathrm{~cm}^{-1}$ & & $\mathrm{~cm}^{-1}$ & $\mathrm{~cm}^{-1}$ & $\mathrm{~cm}^{-1}$ \\
\hline P 38 & 1948. 66 & 1948. 672 & $0.012-$ & $P 22$ & 2025.06 & 2025.069 & $0.009-$ \\
\hline 33 & 1973.40 & 1973. 381 & .019 & 21 & 2029. 61 & 2029. 582 & .028 \\
\hline 32 & 1978.24 & 1978. 233 & .007 & 17 & 2047. 32 & 2047.312 & .008 \\
\hline 31 & 1983.05 & 1983.054 & $.004-$ & 16 & 2051.65 & 2051.664 & $.014-$ \\
\hline 29 & 1992. 63 & 1992.607 & .023 & 15 & 2055.99 & 2055.984 & .006 \\
\hline 28 & 1997.34 & 1997. 338 & .002 & 10 & 2077.10 & 2077.093 & .007 \\
\hline 27 & 2002.02 & 2002.037 & .017 & 9 & 2081. 22 & 2081. 216 & .004 \\
\hline 26 & 2006. 71 & 2006. 706 & .004 & 8 & 2085.31 & 2085. 305 & .005 \\
\hline 25 & 2011.32 & 2011. 343 & $.023-$ & 7 & 2089. 36 & 2089. 360 & .000 \\
\hline \multirow[t]{3}{*}{23} & 2020.50 & 2020.525 & $.025-$ & 5 & 2097.36 & 2097.370 & $.010-$ \\
\hline & \multicolumn{2}{|c|}{$\mathrm{C}^{13} \mathrm{O}^{16}$} & \multirow{2}{*}{$\begin{array}{c}\text { Devi- } \\
\text { ation } \\
\text { obs-calc }\end{array}$} & \multirow[b]{4}{*}{$P=$} & \multicolumn{2}{|c|}{$\mathrm{C}^{13} \mathrm{O}^{16}$} & \multirow{2}{*}{$\begin{array}{c}\text { Devi- } \\
\text { ation } \\
\text { obs-cale }\end{array}$} \\
\hline & Observed & $\begin{array}{l}\text { Calcu- } \\
\text { lated }\end{array}$ & & & Observed & $\begin{array}{l}\text { Calcu- } \\
\text { lated }\end{array}$ & \\
\hline & $\mathrm{cm}^{-1}$ & $\mathrm{~cm}^{-1}$ & $c m^{-1}$ & & $\mathrm{~cm}^{-1}$ & $\mathrm{~cm}^{-1}$ & $\mathrm{~cm}^{-1}$ \\
\hline$P 13$ & 2045.77 & 2045. 788 & $0.018-$ & & 2069.63 & 2069.661 & $0.031-$ \\
\hline 12 & 2049.84 & 2049.845 & $.005-$ & 4 & 2081.20 & 2081.173 & .027 \\
\hline 10 & 2057.88 & 2057.86 & .014 & 3 & 2084.95 & 2084. 946 & .004 \\
\hline 9 & 2061.85 & 2061.830 & .020 & 2 & 2088.68 & 2088.687 & $.007-$ \\
\hline 8 & 2065.78 & 2065. 761 & .019 & 1 & 2092.40 & 2092. 395 & .005 \\
\hline$R 0$ & 2099.69 & 2099. 714 & $.024-$ & $R 10$ & 2134.33 & 2134.320 & .010 \\
\hline 3 & 2110.43 & 2110.447 & $.017-$ & 11 & & 2137.594 & .006 \\
\hline 4 & 2113. 94 & 2113. 958 & $.018-$ & 13 & 2144.05 & 2144.040 & .010 \\
\hline 5 & 2117.43 & 2117.436 & $.006-$ & 17 & 2156.51 & 2156.516 & $.006-$ \\
\hline 7 & 2124. 31 & 2124. 291 & .019 & 18 & 2159.54 & 2159.547 & $.007-$ \\
\hline \multirow{7}{*}{$\begin{array}{r}R 4 \\
5 \\
6 \\
10\end{array}$} & \multicolumn{2}{|c|}{$\mathrm{C}^{12} \mathrm{O}^{18}$} & \multirow{2}{*}{$\begin{array}{c}\text { Devi- } \\
\text { ation } \\
\text { obs-calc }\end{array}$} & \multirow{7}{*}{$\begin{array}{r}R 11 \\
12 \\
14\end{array}$} & \multicolumn{2}{|c|}{$\mathrm{C}^{12} \mathrm{O}^{18}$} & \multirow{2}{*}{$\begin{array}{c}\text { Devi- } \\
\text { ation } \\
\text { obs-calc }\end{array}$} \\
\hline & Observed & $\begin{array}{l}\text { Calcu- } \\
\text { lated }\end{array}$ & & & Observed & $\begin{array}{l}\text { Calcu- } \\
\text { lated }\end{array}$ & \\
\hline & $c m^{-1}$ & $\mathrm{~cm}^{-1}$ & & & $\mathrm{~cm}^{-1}$ & $\mathrm{~cm}^{-1}$ & $c m^{-1}$ \\
\hline & 2109.94 & 2109.940 & 0.000 & & 2133. 52 & 2133. 536 & $0.016-$ \\
\hline & 2113.44 & 2113.437 & .003 & & 2136. 76 & 2136. 739 & .021 \\
\hline & 2116.84 & 2116.847 & $.007-$ & & 2143. 11 & 2143. 118 & $.008-$ \\
\hline & 2130.27 & 2130. 263 & .007 & & & & \\
\hline
\end{tabular}


In figure 4 is shown the absorption spectrum of carbon monoxide. Some of the lines arising from the two isotopic molecules can be seen between the stronger lines of $\mathrm{C}^{12} \mathrm{O}^{16}$. Several lines of water vapor are superimposed on the spestrum in the region from 2,010 to $2,050 \mathrm{~cm}^{-1}$. Because of the low intensity of the isotopic bands, many of the lines of $\mathrm{C}^{12} \mathrm{O}^{16}$ were not appreciably distorted and could be measured with high precision. A total of 10 sets of observations were used in obtaining the values of the wavenumbers of the lines. Great emphasis was placed on making precise measurements of the $\mathrm{CO}$ absorption spectrum, so that molecular constants of high precision could be obtained. Many lines of the bands, arising from $\mathrm{C}^{13} \mathrm{O}^{16}$ and $\mathrm{C}^{12} \mathrm{O}^{18}$ are present in the spectrum. Some of these have been measured, and the values are given in table 2 . The wavenumbers of the calculated and observed values for the rotational lines of the $1-0$ band of $\mathrm{C}^{12} \mathrm{O}^{16}$ are not given in this report, as they have previously been published [3].

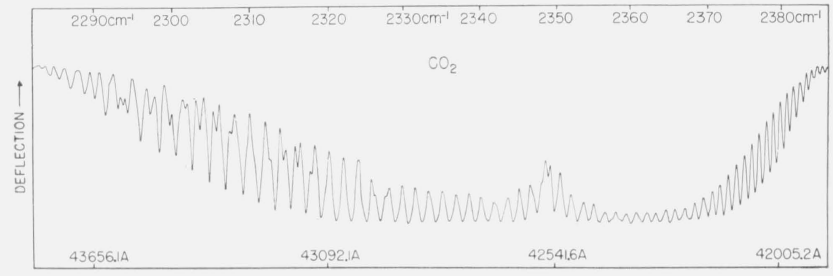

Figure 1. The fundamental band of $\mathrm{CO}_{2}$ at $4.26 \mu$.

The absorption spectrum was measured in an air path of $6 \mathrm{~m}$.
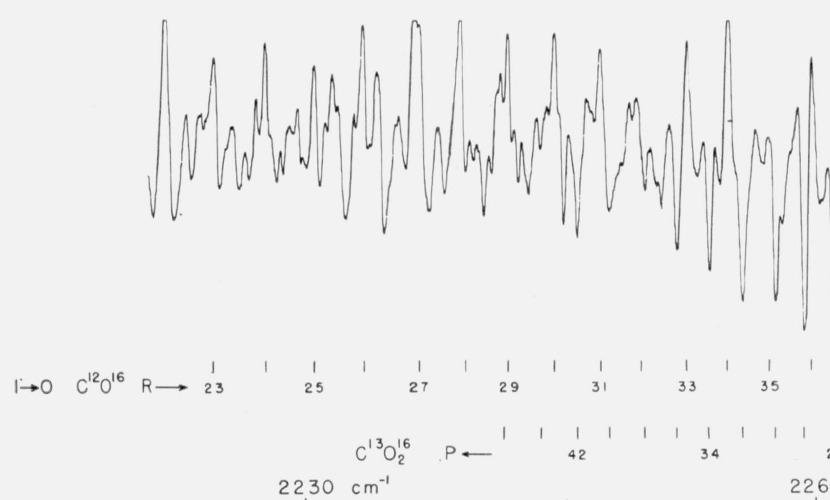
2260
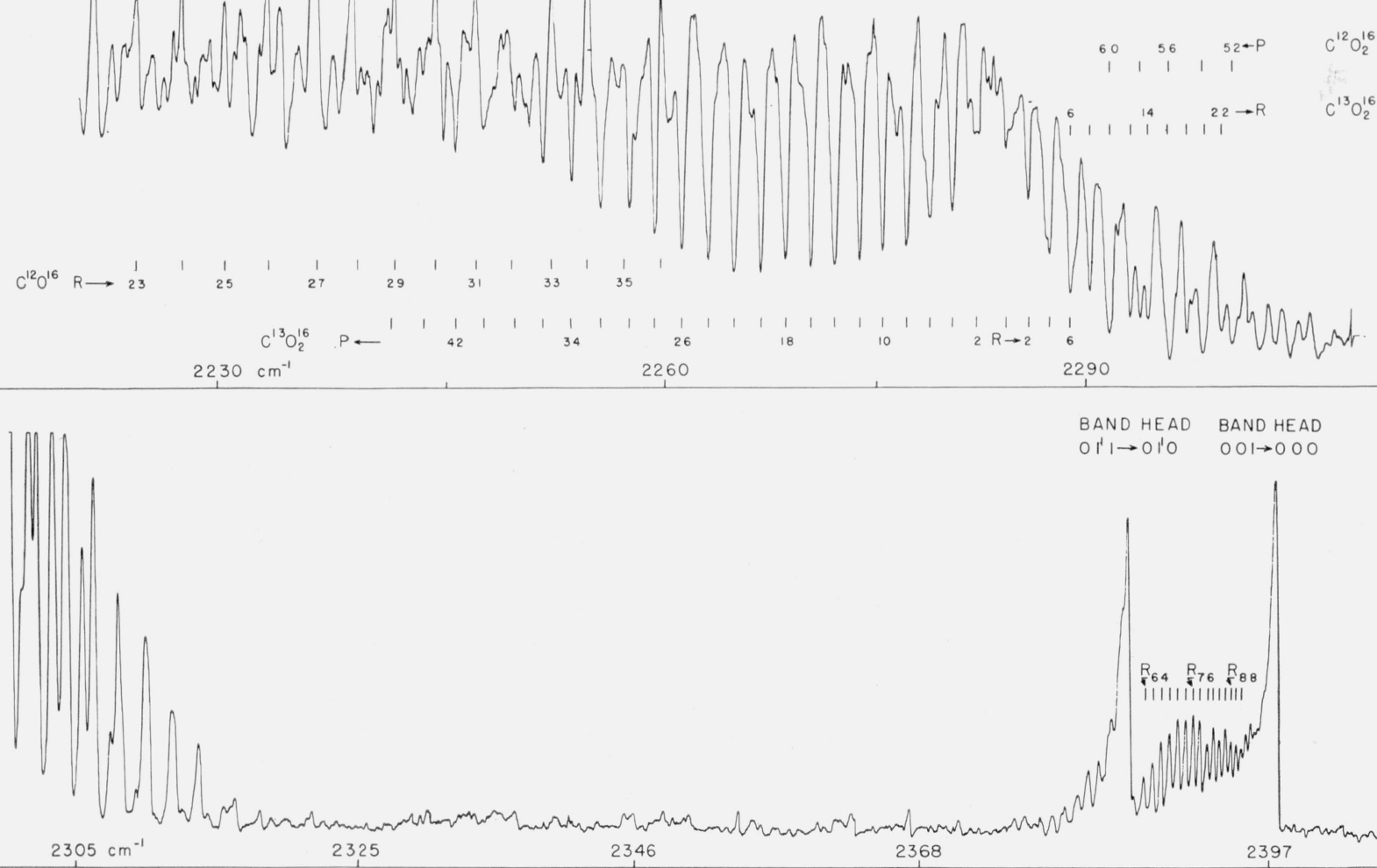
$\begin{array}{ll}\text { BAND HEAD } & \text { BAND HEAD } \\ 0 I^{\prime} \rightarrow 0 I^{\prime} O & \text { OOI } \rightarrow 000\end{array}$

Figure 2. The infrared emission spectrum of $\mathrm{CO}_{2}$ from a rich methane-oxygen flame. From 2,250 to 2,280 $\mathrm{cm}^{-1}$, the atmospheric absorption of $\mathrm{C}^{13} \mathrm{O}_{2}{ }^{18}$ gives rise to an intense group of lines. 


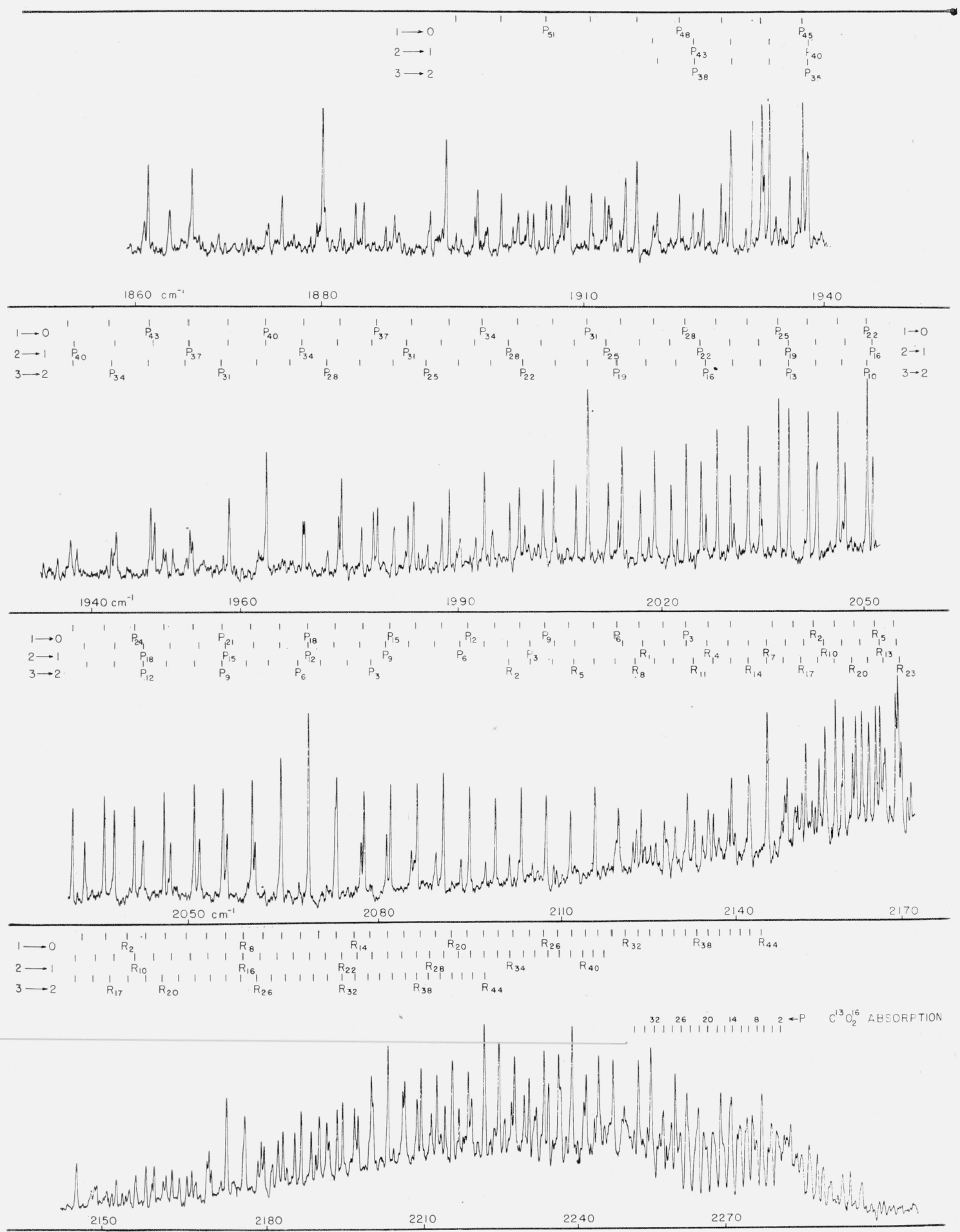

Figure 3. The emission spectrum of CO from 1,860 to 2,170 $\mathrm{cm}^{-1}$.

Many of the lines are identified as belonging to the $3-2,2-1$, and $1-0$ transitions. 


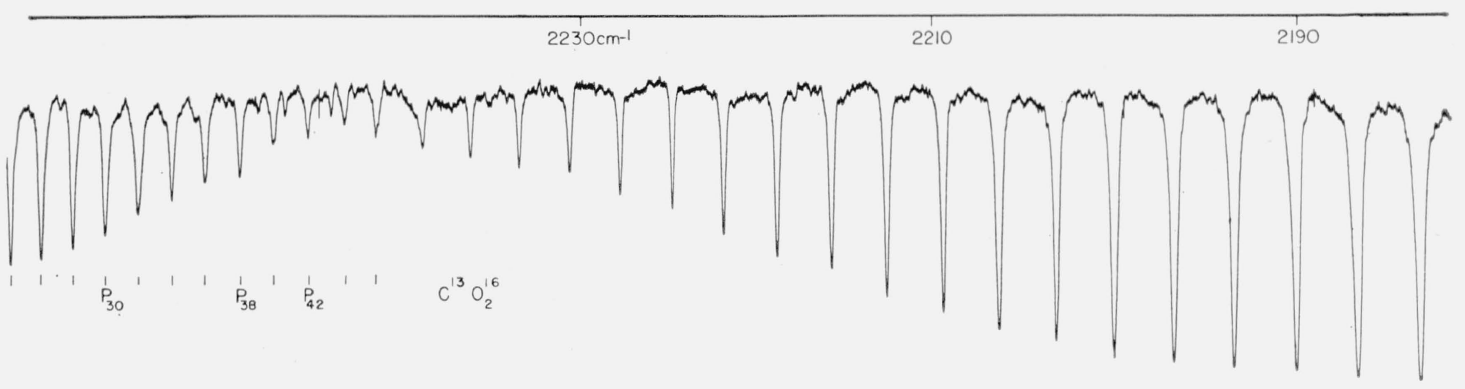

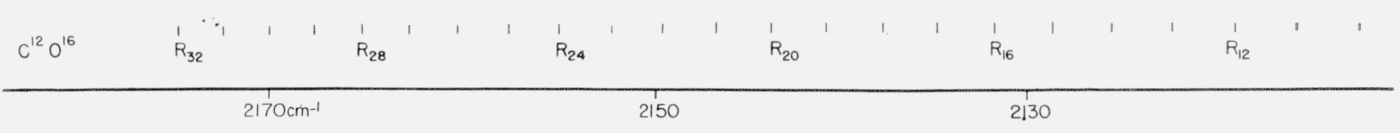

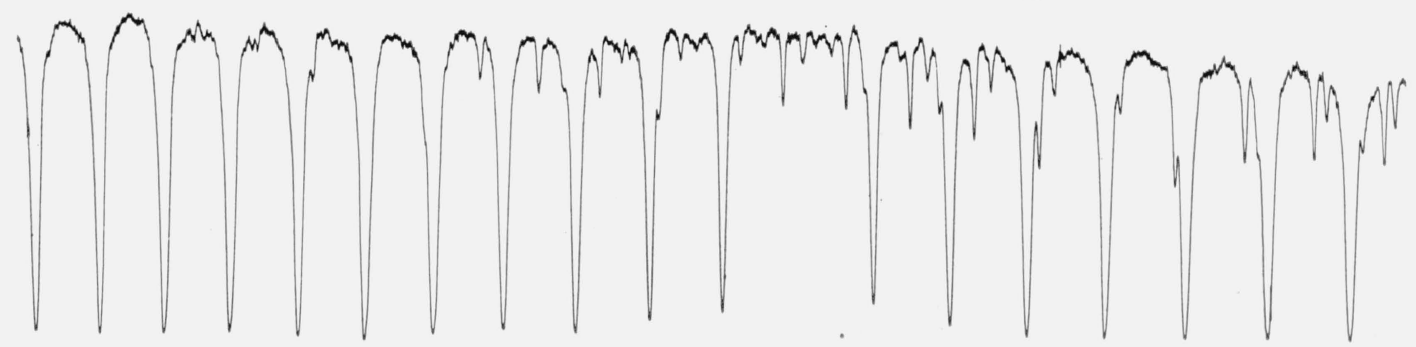

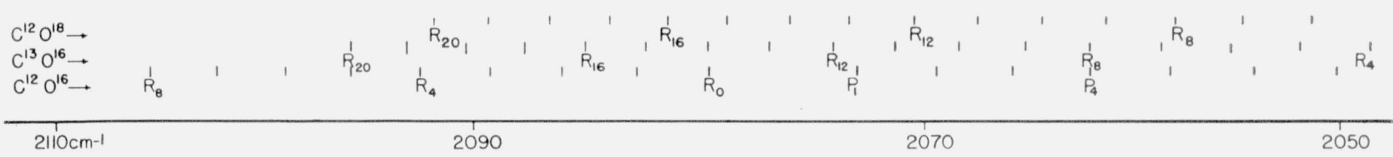
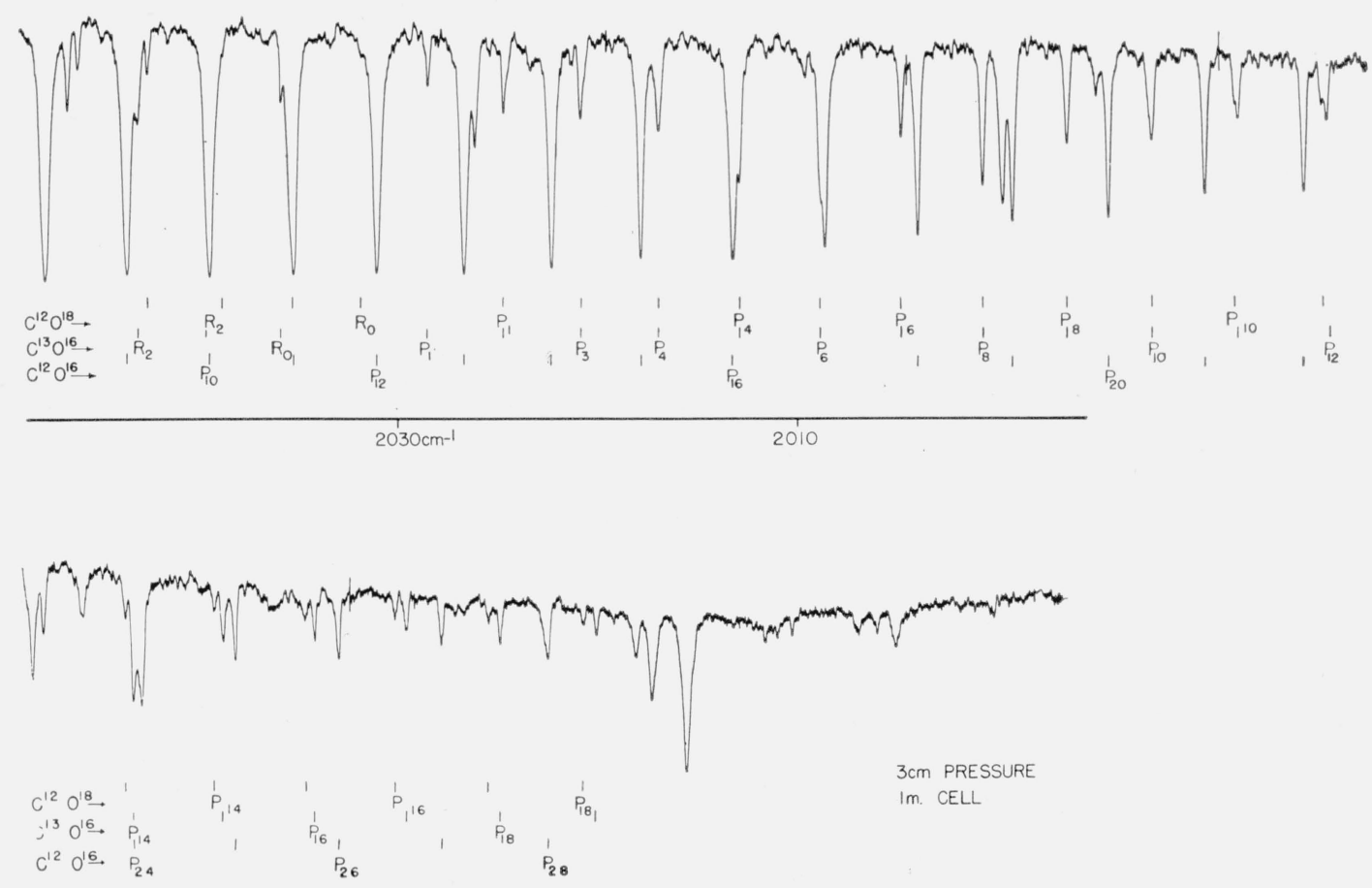

FIGURE 4. The absorption spectrum of $\mathrm{CO}$ in the region from 4.5 to $5 \mu$.

Lines arising from $\mathrm{C}^{12} \mathrm{O}^{16}, \mathrm{C}^{13} \mathrm{O}^{16}$, and $\mathrm{C}^{12} \mathrm{O}^{18}$ can be seen in this region. A cell of 1-m length was used, and the gas pressure was $3 \mathrm{~cm}$ of $\mathrm{Hg}$. 


\section{Discussion of Results}

From the measurements of the bands, which are shown in the figures, molecular constants have been obtained for the carbon monoxide and carbon dioxide molecules. Due to the overlapping of many lines in the emission spectrum, precise measurement could not be made of a sufficient number of the rotational lines in the $R$ branches of the 2-1,3-2, and 4-3 transitions of the $\mathrm{CO}$ bands to obtain the molecular constants for these states to a high precision.

From the measurements of the fundamental band, it has been possible to calculate the molecular constants of $\mathrm{C}^{12} \mathrm{O}^{16}$ to a high precision. The first important attempt to determine the constants of $\mathrm{CO}$ precisely was by Rao [4]. In 1952 Plyler, Benedict, and Silverman [5] made a study of the first overtone bands of $\mathrm{CO}$ in emission and absorption and obtained a set of constants which were not in accord with the results of Rao. These constants were obtained from measurements of the first overtone bands $(2-0,3-1$, 4-2, and 5-3) of $\mathrm{CO}$ and were of good precision. The present work, however, shows that the values for $\omega_{e}, \omega_{e} x_{e}$, and $\omega_{e} y_{e}$ were all slightly in error. The error was caused by the inaccuracy of the $\nu_{0}$ for $3-0$ band of $\mathrm{CO}$. The band center was found to be $6,350.47 \pm 0.05 \mathrm{~cm}^{-1}$, but the present measurements show this band center should be $6,350.42 \mathrm{~cm}^{-1}$ which is at the limit of our estimated precision. This error of $0.05 \mathrm{~cm}^{-1}$ was large enough to create a perceptible difference in our molecular constants. More recently Goldberg and Müller [6] have made a study of the $\mathrm{CO}$ spectrum from the sun. Because of the high temperature of the sun, they were able to observe 6 bands in the first overtone region which had their origin in transitions from the higher energy levels. In addition, the high temperatures made it possible to observe lines with large $J$ values in both the $R$ and $P$ branches. The lines of large $J$ values are very important in the determination of those molecular constants which depend on cubic or quartic powers of the rotational quantum number. A comparison of their values and those obtained in the present work will be discussed later.

In the measurement of the lines in the fundamental band of $\mathrm{C}^{12} \mathrm{O}^{16}$, a Fabry-Perot interferometer was used in determining the wavenumbers of 43 lines which were measured in the absorption spectrum extending from $R_{23}$ to $P_{28}$. Fifteen lines between

TABLE 3. Molecular constants, derived for carbon monoxide $\left(\mathrm{C}^{12} \mathrm{O}^{16}\right)$

\begin{tabular}{|c|c|c|}
\hline Constants & $\begin{array}{l}\text { Goldberg and } \\
\text { Müller }\end{array}$ & Present work \\
\hline $\begin{array}{l}\omega_{e} \\
\omega_{e} X_{e} \\
\omega_{e} Y_{e} \\
B_{e} \\
\alpha_{e} \\
\gamma_{e} \\
D_{e} \\
\beta_{e}\end{array}$ & $\begin{array}{l}\text { cm-1 } \\
\text { 2169. } 83 \\
\text { 13. } 297 \\
\text { 0. } 0115 \\
\text { 1. } 93141 \\
\text { 0. } 017520 \\
2.96 \times 10^{-6} \\
\text { 6. } 18 \times 10^{-6} \\
-1.76 \times 10^{-8}\end{array}$ & $\begin{array}{l}\mathrm{cm}^{-1} \\
\text { 2169. } 830 \pm 0.004 \\
\text { 13. } 297 \pm 0.017 \\
\text { 0. } 01150 \pm 0.00014 \\
\text { 1. } 93130 \pm 0.00005 \\
\text { 0. } 017520 \\
\text { 4. } 5 \times 10^{-6} \\
\text { 6. } 26 \times 10^{-6} \\
-2.99 \times 10^{-8}\end{array}$ \\
\hline
\end{tabular}

$P_{32}$ and $P_{52}$ were measured in emission. By least squares the lines were fitted to the equation

$$
\begin{aligned}
\nu=\nu_{0}+\left(B_{1}+B_{0}\right) m+ & \left(B_{1}-B_{0}-D_{1}+D_{0}\right) m^{2} \\
& -2\left(D_{1}+D_{0}\right) m^{3}-\left(D_{1}-D_{0}\right) m^{4}
\end{aligned}
$$

where $B_{0}$ is proportional to the reciprocal of the moment of inertia in the ground state, and $D_{0}$ is proportional to the centrifugal distortion. $B_{1}$ and $D_{1}$ are the same type of constants for the excited state. The constants obtained are as follows

$$
\begin{aligned}
\nu_{0} & =2143.274 \pm 0.003 \mathrm{~cm}^{-1}, \\
B_{1} & =1.904994 \pm 0.000036 \mathrm{~cm}^{-1}, \\
B_{0} & =1.922523 \pm 0.000037 \mathrm{~cm}^{-1}, \\
D_{0} & =6.26 \pm 0.025 \times 10^{-6} \mathrm{~cm}^{-1}, \text { and } \\
D_{1}-D_{0} & =-2.99 \times 10^{-9} \mathrm{~cm}^{-1} .
\end{aligned}
$$

The values obtained for $B_{0}$ and $D_{0}$ are in excellent agreement with the same constants determined by microwave measurements [7] if the velocity of light is, $c=299,792 \mathrm{~km} / \mathrm{sec}$. From the measurements on the fundamental band and the previous measurements of the first overtone, a new set of constants have been determined on the basis of the present work. These constants and those obtained by Müller and Goldberg are listed in table 3. In the calculation of $\omega_{e}, \omega_{e} x_{e}$, and $\omega_{e} y_{e}$ the $7-5$ and $6-4$ harmonics, measured by Goldberg and Müller, have been used in addition to the $1-0,2-0,4-2$, and 5-3 transitions measured in this laboratory. A comparison of the constants of Goldberg and Müller with those obtained in this work, shows that there is excellent agreement. The value of $B_{e}$ obtained by Goldberg and Müller is $1 \times 10^{-4}$ larger than the value calculated from our results. The small differences in $\gamma_{e}$ and $\beta_{e}$ are unimportant. Only under the best circumstances can these constants be determined with any degree of accuracy. Often the data are not sufficiently accurate to obtain the correct sign for these constants. On account of the use of a large range of quantum numbers of rotation and of vibration, the values of Goldberg and Müller for $\gamma_{e}$ and $\beta_{e}$ should be more accurate than the ones obtained from the present measurements, and they are in better agreement with the theoretical values.

McCulloh and Glockler [8] have measured the emission bands of $\mathrm{C}^{13} \mathrm{O}^{16}$ in the region from 1900 to $6500 \mathrm{~A}$ and from these results have calculated the $\omega_{e}, \omega_{e} x_{e}$, and $\omega_{e} y_{e}$ for $\mathrm{C}^{13} \mathrm{O}^{16}$ and $\mathrm{C}^{12} \mathrm{O}^{16}$. Their values for $\mathrm{C}^{12} \mathrm{O}^{16}$ are $\omega_{e}=2,169.84 \mathrm{~cm}^{-1}, \omega_{e} x_{e}=13.301 \mathrm{~cm}^{-1}$, and $\omega_{e} y_{e}=0.0123 \mathrm{~cm}^{-1}$. These values are in good agreement with those listed in table 3 , but they are slightly larger than the same constants calculated from the infrared bands.

In addition to the fundamental band of $\mathrm{C}^{12} \mathrm{O}^{16}$ at $4.67 \mu$, there are two weak bands which overlap it produced by $\mathrm{C}^{13} \mathrm{O}^{16}$ and $\mathrm{C}^{12} \mathrm{O}^{18}$. The rotational lines of these bands are in some cases superimposed on the lines of $\mathrm{C}^{12} \mathrm{O}^{16}$. Mills and Thompson [9] have made 
a measurement of 33 lines of the $\mathrm{C}^{13} \mathrm{O}^{16}$ isotopic band. They used the calculated position of the fundamental band of $\mathrm{C}^{12} \mathrm{O}^{16}$ for calibration. The fundamental band was calculated by them from the measurements in this laboratory of the first overtone band. The agreement of the measurements of Mills and Thompson, compared with measurements on 20 lines in this laboratory, are excellent. It indicates that with proper calibration high precision measurements can be made on infrared bands.

The constants obtained from the two sets of data are in good agreement and are shown in table 4 . Seven lines of the $R$ branch of the fundamental band of $\mathrm{C}^{12} \mathrm{O}^{18}$ were found to be in close agreement with the values obtained by Mills and Thompson for this band. These lines are listed in table 2 .

On account of the intense absorption of the $\mathrm{CO}_{2}$ in the $6-\mathrm{m}$ path, the lines near the center of the 001-000 band could not be measured. A total of 36

TABLE 4. Molecular constants $\mathrm{C}^{13} \mathrm{O}^{16}$

\begin{tabular}{|c|c|c|}
\hline Constants & $\begin{array}{l}\text { Mills and } \\
\text { Thompson }\end{array}$ & Present work \\
\hline $\begin{array}{l}R_{1} \\
B_{0} \\
\gamma \\
D_{2} \\
\omega_{e}-\ldots \\
\omega_{e} x_{e} \\
\nu_{0}\end{array}$ & $\begin{array}{l}\text { cm-1 } \\
\text { 1. } 8218 \\
\text { 1. } 8382 \\
0.01645 \\
5.4 \times 10^{-6} \\
\text { 2111. } 41 \\
\text { 12. } 67 \\
2096.07\end{array}$ & $\begin{array}{l}c m^{-1} \\
1.8216 \\
1.8380 \\
0.01633 \\
5.8 \times 10^{-6} \\
2141.41 \\
12.67 \\
2096.071\end{array}$ \\
\hline
\end{tabular}

lines, however, were measured, and the constants were calculated by least squares using a cubic degree equation.

The agreement between the observed and calculated wavenumbers for the lines is shown in table 1. The position of any line can be obtained from the equation

$$
\begin{aligned}
\nu= & 2,349.16+0.77743 m-0.0030926 m^{2}- \\
& 0.000000504 m^{3}
\end{aligned}
$$

where $m=J+1$ for the $R$ branch and $m=-J$ for the $P$ branch.

$$
\begin{aligned}
\nu_{0} & =2,349.16 \pm 0.01 \mathrm{~cm}^{-1} \\
B_{0} & =0.39026 \pm 0.00005 \\
D_{0} & =12.6 \pm 0.8 \times 10^{-8}
\end{aligned}
$$

$B_{0}$ was previously calculated from $3 \nu_{3}$, and a value of $0.3902 \mathrm{~cm}^{-1}$ was found from that band. This is in good agreement with the present results [10]. These measurements are not as precise as those made on CO. The lines were broadened by the atmospheric pressure, and in many cases the absorption was too large, making it impossible to obtain the center of the line with precision.

Sixteen lines in the $P$ branch of $\mathrm{C}^{13} \mathrm{O}_{2}{ }^{16}$ have been measured. These lines are listed in table 1 . The value of $\nu_{0}$ was found to be $2,285.056 \mathrm{~cm}^{-1}$. The estimated standard deviation of the lines from the calculated values is $0.006 \mathrm{~cm}^{-1}$. The other molecular constants were not determined.

Because of overlapping it was not felt that sufficient lines of the 3-2 transition of $\mathrm{CO}$ could be measured with good accuracy so that reliable molecular constants could be obtained. This band can be obtained with greater precision by calculation from the other levels.

The authors express their appreciation to Joseph M. Cameron of the Statistical Engineering Section of this Bureau for assistance in making the least squares computations on the electronic computer, SEAC.

\section{References}

[1] G. Herzberg, Molecular spectra and molecular structure I diatomic molecules; II polyatomic molecules (D. Van Nostrand Co., Inc., New York, N. Y.).

[2] Earle K. Plyler and Joseph J. Ball, J. Chem. Phys. 20, 1178 (1952)

[3] Plyler, Blaine, and Connor, J. Opt. Soc. Am. 45, 102 (1955).

[4] K. N. Rao, J. Chem. Phys. 18, 213 (1950).

[5] Plyler, Benedict, and Silverman, J. Chem. Phys. 20, 175 (1952).

[6] Leo Goldberg and Edith A. Müller, Astrophys. J. 118, 397 (1953).

[7] Gilliam, Johnson, and Gordy, Phys. Rev. 78, 140 (1950). Bedard, Gallaghen, and Johnson, Phys. Rev. 92, 1440 (1953).

[8] K. E. MeCulloh and G. Glockler, Phys. Rev. 89, 145 (1953).

[9] I. M. Mills and H. W. Thompson, Trans. Far. Soc. 49, 224 (1953).

[10] Norman M. Gailar and Earle K. Plyler, J. Research NBS, 48, 392 (1952) RP2327.

Washington, April 22, 1955 